\title{
Urease $(E C 3.5 .1 .5)$ inhibition in the sheep rumen and its effect on urea and nitrogen metabolism
}

\author{
BY F. G. WHITELAW, J. S. MILNE AND SHELLEY A. WRIGHT \\ Rowett Research Institute, Bucksburn, Aberdeen AB2 9SB
}

(Received 30 May 1990 - Accepted 30 November 1990)

\begin{abstract}
The urease (EC 3.5.1.5) inhibitor, phenylphosphoryldiamidate (PPDA), was given by continuous infusion into the rumen of two sheep nourished by intragastric infusion and into either the rumen or abomasum of four sheep given a pelleted diet containing $119 \mathrm{~g}$ crude protein (nitrogen $\times 6.25$ ) $/ \mathrm{kg}$ dry matter. PPDA was given at $1 \mathrm{~g} / \mathrm{d}$ in infusion sheep and $1.5 \mathrm{~g} / \mathrm{d}$ in the normally-fed sheep. Measurements of urea kinetics were made using single injections of $\left[{ }^{14} \mathrm{C}\right]$ urea. Urease inhibition was complete within $24 \mathrm{~h}$ of starting PPDA infusions to the rumen; in this time-period, urea concentration in rumen contents reached equilibrium with that in plasma and this situation persisted until infusions were terminated. Relative to the control periods, plasma urea and rumen ammonia concentrations were unchanged but urea irreversible loss rate decreased by $26 \%$ in infusion sheep and $33 \%$ in fed sheep when PPDA was given. Urinary urea excretion was not affected, hence urea degradation, measured by difference, decreased by 77 and $58 \%$ respectively in response to urease inhibition. Administration of PPDA to the abomasum resulted in a reduction in rumen urease activity to about $40 \%$ of control values but had no effect on urea metabolism. Differences between treatments in daily nitrogen retention were not significant, indicating that under the dietary conditions imposed in these experiments, even substantial changes in urea recycling had only minor effects on the overall $N$ economy of the animal.
\end{abstract}

Ruminant: Urea : Urease: Kinetics

The enzyme urease (EC 3.5.1.5) is produced by certain rumen and intestinal bacteria and serves an essential function in the process of urea recycling by catalysing the conversion of urea to ammonia. In ruminant species, urease activity is greatest within the stratified layers of the rumen epithelium (Abdel Rahman \& Decker, 1966; Cheng et al. 1979) and has been shown to be associated with the adherent, facultatively anaerobic and strongly proteolytic bacterial population which colonizes this tissue (McCowan et al. 1978; Cheng et al. 1979). Urease activity in rumen fluid is thought to result mainly from the sloughing of heavily-colonized distal epithelial cells from the keratinized layers of the epithelium (Cheng et al. 1979; Dinsdale et al. 1980).

The role of urease in facilitating the transfer of urea from blood to rumen contents was demonstrated in the classical experiments of Houpt \& Houpt (1968). These workers used combinations of antimicrobial agents, enzymic inhibitors and frequent rinsing to eliminate urease activity from rumen pouch preparations and showed that the transfer of ureanitrogen from blood to pouch was much more rapid in the presence than in the absence of urease. This they attributed to the smaller size and greater lipid solubility of the $\mathrm{NH}_{3}$ molecule, which allowed it to penetrate and diffuse through the cornified layers of the epithelium at a faster rate than urea (Houpt \& Houpt, 1968; Houpt, 1970).

The inhibition of urease activity in vivo in the normally-functioning ruminant would clearly allow the rumen $v$. post-rumen components of urea recycling to be identified and 
could provide information also on the effect of urea recycling on the $\mathrm{N}$ economy of the host animal. To date, however, attempts to use this experimental approach in animals consuming normal feeds have been frustrated by the lack of a suitable inhibitor of urease. Of the better-known compounds which possess this property (e.g. quinones, dihydric phenols, phenylmercuric acetate, boric acid), most are toxic irritants and are unsuitable for long-term use in vivo. Acetohydroxamate is an exception, but the use of this compound to restrict the rate of breakdown of urea given as a feed supplement to sheep has been unsuccessful because of the rapid adaptation of rumen microbes to the inhibitor (Streeter et al. 1969; Jones \& Milligan, 1975).

The discovery that phosphoramidate, a structural analogue of urea, produced reversible inhibition of urease (Dixon et al. 1975) has led in recent years to the synthesis of a new range of urease inhibitors. Of these, phenylphosphoryldiamidate (PPDA) has proved to be one of the most potent compounds (Liao \& Raines, 1985), and has given promising results as an inhibitor of soil urease activity when used in conjunction with urea-based fertilizers (Vlek et al. 1980; Byrnes et al. 1983). The only reports on the use of PPDA in animals are those of Voigt and co-workers who examined the use of this material in the diet of dairy cows. Only a modest reduction in urease activity was achieved although the rate of urea hydrolysis and the concentration of $\mathrm{NH}_{3}$ in rumen fluid both decreased during the early part of the 24-week treatment period (Voigt et al. 1980). Subsequently, no improvement in milk yield was observed when PPDA was given to dairy cows at levels of 370 or $740 \mathrm{mg} / \mathrm{d}$ and the authors concluded that urease inhibition was without practical significance at the level of urea supplementation employed (Piatkowski \& Voigt, 1981).

The present paper reports the results of investigations with PPDA in sheep. The quantities given daily in these experiments were considerably higher than those used by Piatkowski \& Voigt (1981) in cows, and were effective in inhibiting urease activity in vivo; preliminary trials had indicated that these quantities had no obvious deleterious effects on the animals.

\section{METHODS}

Animals, diets and management

Six sheep were used in three experiments. Two female, Suffolk $\times$ Scottish Blackface sheep of about 9 months of age and $36 \mathrm{~kg}$ mean live weight were used in Expt 1. Two similar Suffolk $\times$ Scottish Blackface sheep and one male and one female Finn $\times$ Dorset lambs of about 7 months of age and $35 \mathrm{~kg}$ mean live weight were used in Expt 2. Expt 3 was a slaughter experiment and involved all six of the above sheep. All sheep were fitted with a cannula in the rumen and infusion catheters in the abomasum some weeks before the experiments began, as described by Ørskov et al. (1979). The four Suffolk $\times$ Scottish Blackface sheep had been used previously in a study of urea metabolism (Whitelaw et al. 1991) and had been maintained for several weeks by the intragastric nutrition procedures described by Ørskov et al. (1979).

The two sheep used in Expt 1 continued to receive the intragastric infusion regimen employed in the previous study (Whitelaw et al. 1991). A standard volatile fatty acids (VFA) solution containing acetic, propionic and $n$-butyric acids in the molar proportions $0.65,0.25$, and 0.10 respectively was infused into the rumen together with the major minerals in a total daily volume of 3.4 litres. The appropriate quantity of buffer solution was infused separately into the rumen in a total daily volume of 6.4 litres. Lactic casein was the sole source of $\mathrm{N}$ and was infused into the abomasum in a daily volume of 3.4 litres. At the end of Expt 1 the intragastric infusions were stopped and both animals were realimented on a diet of chopped hay and concentrates and given inoculations of rumen digesta from conventionally-fed sheep. When normal food intake was established, both 
Table 1. Plan of Expts 2 and 3: 'control 1' was infusion of water into the rumen, 'control 2' was infusion of water into the abomasum; phenylphosphoryldiamidate (PPDA) was given by continuous infusion into the rumen or abomasum at a level of $1.5 \mathrm{~g} / \mathrm{d}$

\begin{tabular}{|c|c|c|c|c|c|c|}
\hline \multirow[b]{2}{*}{ Period.... } & \multicolumn{5}{|c|}{ Expt 2} & \multirow[b]{2}{*}{ Expt 3} \\
\hline & 1 & 2 & 3 & 4 & 5 & \\
\hline Sheep A, B & $\begin{array}{c}\text { Control } \\
1\end{array}$ & $\begin{array}{c}\text { PPDA } \\
\text { (rumen) }\end{array}$ & $\begin{array}{c}\text { Control } \\
1\end{array}$ & $\begin{array}{c}\text { PPDA } \\
\text { (abomasum) }\end{array}$ & $\begin{array}{c}\text { Control } \\
2\end{array}$ & $\begin{array}{c}\text { PPDA } \\
\text { (rumen) }\end{array}$ \\
\hline Sheep C, D & $\begin{array}{c}\text { Control } \\
2\end{array}$ & $\begin{array}{c}\text { PPDA } \\
\text { (abomasum) }\end{array}$ & $\begin{array}{c}\text { Control } \\
2\end{array}$ & $\begin{array}{c}\text { PPDA } \\
\text { (rumen) }\end{array}$ & $\begin{array}{c}\text { Control } \\
1\end{array}$ & $\begin{array}{c}\text { PPDA } \\
\text { (abomasum) }\end{array}$ \\
\hline Duration (d) & 14 & 10 & 14 & 10 & 14 & 5 \\
\hline
\end{tabular}

animals were changed to the diet described for Expt 2 and were maintained on this diet for about 6 weeks before slaughter in Expt 3 .

The composition of the diet given to the sheep in Expt 2 was $(\mathrm{g} / \mathrm{kg}) ; \mathrm{NH}_{3}$-treated straw, 800 ; unmolassed sugar beet pulp, 150; molasses, 20; casein, 22; mineral-vitamin supplement, 8. The $\mathrm{NH}_{3}$-treated straw was prepared as described by Ørskov et al. (1983), and was ground through a $40 \mathrm{~mm}$ screen in a hammermill before inclusion in the mixture. The complete diet was then pelleted through a $12 \mathrm{~mm}$ die. By analysis, the diet contained $19.05 \mathrm{~g} \mathrm{~N} / \mathrm{kg}$ dry matter (DM) and had an estimated metabolizable energy value of $9 \cdot 6 \mathrm{MJ} / \mathrm{kg} \mathrm{DM}$. The daily allowance of this diet was $665 \mathrm{~g} \mathrm{DM}$ and this was given continuously from an endless-belt feeding device. This intake provided energy for maintenance $+0.05 \mathrm{~kg}$ daily live-weight gain and supplied $12.7 \mathrm{~g} \mathrm{~N} / \mathrm{d}$ of which an estimated $8.3 \mathrm{~g}$ was rumen-degradable N (Agricultural Research Council, 1984).

The two animals in Expt 2 which had previously been subjected to intragastic nutrition (Whitelaw et al. 1991) had been re-alimented on solid food and were introduced to the experimental diet four weeks before measurements were made. Throughout Expts 1 and 2 all animals were housed in metabolism cages equipped for the separate collection of faeces and urine and had fresh water available $a d$ lib. at all times.

\section{Design and treatments}

Expt 1. The effect of PPDA on urease activity and on urea and $\mathrm{N}$ metabolism was examined in two sheep nourished by intragastric infusion. A single change-over design was used in which each animal received two treatments in two successive $10 \mathrm{~d}$ periods: treatment $A$ was the standard intragastric infusion procedure described by Whitelaw et al. (1991) with daily energy input equivalent to the estimated requirement for maintenance and a daily $\mathrm{N}$ input of 1.05 times maintenance. Treatment $\mathrm{B}$ was the same as treatment A, except that both animals received in addition a continuous intrarumen infusion of PPDA for a period of $8 \mathrm{~d}$. PPDA was given at a level of $1.0 \mathrm{~g} / \mathrm{d}$ in a total volume of $320 \mathrm{ml}$ water and was infused separately from the other nutrient solutions. Both animals received treatment $A$ followed by treatment $B$.

Expt 2. The effect of PPDA on urease activity and on urea and $\mathrm{N}$ metabolism was measured in animals given a normal ruminant diet. PPDA was given by infusion into either the rumen or the abomasum of four animals according to a change-over design in which each period of PPDA administration was preceded and followed by a period in which water alone was infused. The sequence and duration of treatments is given in Table 1, in which the four sheep used are designated A, B, C and D; 'control 1 ' represents water infusion to the rumen $(1000 \mathrm{ml} / \mathrm{d})$ and 'control 2' represents water infusion to the abomasum 
$(320 \mathrm{ml} / \mathrm{d})$. PPDA was given at $1.5 \mathrm{~g} / \mathrm{d}$ in daily volumes of $1000 \mathrm{ml}$ and $320 \mathrm{ml}$ to rumen and abomasum respectively. There were thus six observations on each of the 'control' treatments and four observations on each PPDA treatment.

Expt 3. At the end of Expt 2, the four sheep were subjected to a further period in which PPDA was infused into the rumen or abomasum for $5 \mathrm{~d}$ (Table 1 ) in order to obtain information on the effect of PPDA administration on urease activity in different segments of the gastrointestinal (GI) tract. Animals were killed with an intravenous overdose of pentobarbitone (Euthesate; Willows Francis Veterinary, Horsham, Sussex) and the GI tract quickly separated by ligatures into seven segments before removal from the carcase. The two animals from Expt 1 were used as controls; these animals had been accustomed to the same diet as used in Expt 2 (p. 211) and were returned to metabolism cages and given infusions of water alone into rumen or abomasum for $7 \mathrm{~d}$ before slaughter.

\section{Measurements and sampling procedures}

Expt 1. In each $10 \mathrm{~d}$ period, days 3-7 inclusive $(5 \mathrm{~d})$ were used for quantitative collection of faeces and urine for $\mathrm{N}$ balance, and the kinetics of urea metabolism and the variables associated with rumen function were measured over days 9 and 10. The infusion of PPDA into the rumen in period 2 took place over days $3-10$ inclusive, during which urease activity in rumen fluid was monitored daily. The methods used in estimating urea pool size and irreversible loss rate (ILR) were as described by Whitelaw et al. (1990). A single injection of $\left[{ }^{14} \mathrm{C}\right]$ urea $(50 \mu \mathrm{Ci}, 6.25 \mathrm{mg}$ urea) in $10 \mathrm{ml}$ isotonic saline ( $9 \mathrm{~g}$ sodium chloride $/ 1)$ was given into a jugular vein via an indwelling polythene catheter and the catheter was flushed with a further $10 \mathrm{ml}$ saline. Samples of blood for the measurement of urea concentration and plasma urea specific radioactivity were taken from a catheter in the other jugular vein before injection and at intervals of $5 \mathrm{~min}$ (four samples), then $10 \mathrm{~min}$ ( 1 sample), $15 \mathrm{~min}$ (two samples), $20 \mathrm{~min}$ (three samples), $2 \mathrm{~h}$ (two samples) and then at $12 \mathrm{~h}, 23.5 \mathrm{~h}$ and $24.5 \mathrm{~h}$. Samples of rumen fluid for the measurement of $\mathrm{pH}$, osmotic pressure, $\mathrm{NH}_{3}$ concentration and molar proportions of VFA were taken via the rumen cannula $10 \mathrm{~min}$ before injection and at 100,210,320,440, and $540 \mathrm{~min}$ after injection. The kinetics of urea metabolism were assumed to conform to a two-compartment model consisting of a main pool and a side pool, in which urea enters and leaves the system only via the main pool. The observed values for plasma urea specific radioactivity were normalized and the maximum likelihood programme of Ross (1980) was used to establish the parameters of the double exponential curve which best fitted the decline in specific activity with time. Urea pool size and ILR were estimated from the curve parameters using the relationships given by Nolan \& Leng (1974). The total pool of urea was taken as the sum of the main pool and the side pool.

Expt 2. Collections of faeces and urine for $\mathrm{N}$ balance and digestibility measurements were made over $5 \mathrm{~d}$, and the kinetics of urea metabolism and variables of rumen fermentation were measured over $2 \mathrm{~d}$ during the final $8 \mathrm{~d}$ of each of the five treatment periods. The activity of urease in rumen fluid was measured daily in the periods in which PPDA was infused and at intervals of 3-4 d during the "control' periods. In addition, the time-course of urease inhibition and of changes in rumen metabolites at the start of PPDA infusions, and the restoration of urease activity when PPDA infusions were terminated, were examined in the two sheep given PPDA into the rumen in period 4 (Table 1).

Samples of whole rumen contents from each sheep were fixed with an equal volume of formalin $(40 \mathrm{ml} / \mathrm{l})$ at the start of period 1 and on the final day of each of periods $2-5$. These samples were examined microscopically for the presence of ciliate protoza and for the morphological types of bacteria present. Counts of ciliate protozoa were made on the samples taken in period 3 . 
Expt 3. The segments of the GI tract isolated by double ligatures were (1) rumenreticulum-omasum, (2) abomasum, (3) duodenum, (4) jejunum, (5) ileum, (6) colon and (7) remainder of large intestine, excluding rectum. These segments were separated by incising between the ligatures and the digesta contained in each segment was quickly transferred to a container held in ice. After mixing, subsamples were taken for an immediate $\mathrm{pH}$ measurement and urease assay, and the remainder was held at $-20^{\circ}$ until analysed for urea and $\mathrm{NH}_{3}$. The time-interval from slaughter to transfer of samples to cold store was about $30-40 \mathrm{~min}$ for each animal.

\section{Analytical methods}

All methods used in the analysis of feed, faeces, urine, rumen contents and blood samples have been described previously (Oncuer et al. 1990; Whitelaw et al. 1990; Whitelaw \& Milne, 1991). Urea concentration in rumen fluid was invariably very low in the 'control' periods and required a modification of the usual urea assay method (Marsh et al. 1965) to accommodate a larger sample volume.

\section{Calculations and statistical methods}

Urea degradation in the GI tract was taken as the difference between ILR and the rate of excretion of urea in urine over the $48 \mathrm{~h}$ following ${ }^{14} \mathrm{C}$ administration. Urea space was calculated as urea pool size (mg) divided by plasma urea concentration $(\mathrm{mg} / \mathrm{l})$ and expressed as a proportion of body weight $(1 / \mathrm{kg})$.

The six observations for each variable in the two 'control' periods and the four observations for each of the two PPDA treatments in Expt 2 were subjected to an analysis of variance which allowed treatment means to be adjusted for animal and period effects. All statistical analyses were performed using Genstat (1987).

\section{RESULTS \\ Expt 1}

The effects of PPDA infusion on urea and nitrogen metabolism of sheep sustained by intragastric nutrition are given in Table 2. Inhibition of urease activity in rumen fluid was virtually complete ( $>98 \%$ ) within $24 \mathrm{~h}$ of starting PPDA infusion, and urease remained barely detectable throughout the infusion period. This was accompanied by a dramatic increase in the concentration of urea in rumen fluid to a level similar to that of plasma, and by a decrease of over $40 \%$ in rumen $\mathrm{NH}_{3}$ concentration. Relative to the measurements made in the 'control' period, urea ILR decreased by about $26 \%$ when PPDA was given but there was no change in urinary urea excretion. In consequence, the degradation of urea in the GI tract decreased by some $70 \%(5.16 \mathrm{~g} / \mathrm{d})$ in response to the inhibition of urease. PPDA infusions also resulted in increases in plasma urea concentration and in urea pool size, and there was an indication that the daily $\mathrm{N}$ retention of the animal was enhanced when urease activity was inhibited (Table 2). Addition of PPDA to the rumen had no effect on $\mathrm{pH}$ or osmotic pressure or on the molar proportions of VFA in rumen fluid.

\section{Expt 2}

Rumen conditions. Infusion of PPDA to the rumen of sheep given a normal ruminant diet had an immediate effect on rumen urease activity (Table 3). Again, inhibition was virtually complete and the effect persisted for as long as PPDA infusions were maintained. Urease activity in the rumen was at all times significantly lower than on any other treatment $(P<0.001)$ and, as in Expt 1 , this change was accompanied by the accumulation of urea in rumen contents $(P<0.001)$. The addition of PPDA to the rumen resulted in an increase in the molar proportion of propionic acid $(P<0.05)$ and a decrease in acetic acid 
Table 2. Expt 1. Urea and nitrogen metabolism of two sheep sustained by intragastric infusion of all nutrients, with or without a continuous infusion of the urease (EC 3.5.1.5) inhibitor, phenylphosphoryldiamidate (PPDA), to the rumen*

(Mean values and standard deviations; df 2)

\begin{tabular}{|c|c|c|c|c|}
\hline & \multicolumn{2}{|c|}{ 'Control' } & \multicolumn{2}{|c|}{ + PPDA } \\
\hline & Mean & $\mathrm{SD}$ & Mean & SD \\
\hline Live weight $(\mathrm{kg})$ & $36 \cdot 2$ & 1.76 & $36 \cdot 2$ & $1 \cdot 76$ \\
\hline \multicolumn{5}{|l|}{ Rumen } \\
\hline Urease activity $\left(\mu \mathrm{mol} \mathrm{NH}_{3} / \mathrm{min}\right.$ per $\mathrm{ml}$ fluid) & $2 \cdot 33$ & 0.33 & $0 \cdot 03$ & $0 \cdot 02$ \\
\hline Ammonia concentration $(\mathrm{mg} / \mathrm{l})$ & $86-5$ & $9 \cdot 8$ & $50 \cdot 0$ & $64 \cdot 0$ \\
\hline Urea concentration $(\mathrm{mg} / \mathrm{l})$ & 0.9 & 0.0 & $136 \cdot 5$ & $24 \cdot 0$ \\
\hline \multicolumn{5}{|l|}{ Urea metabolism } \\
\hline Plasma concentration $(\mathrm{mg} / \mathrm{l})$ & $104 \cdot 2$ & 0.63 & $135 \cdot 1$ & $13 \cdot 4$ \\
\hline Irreversible loss rate (ILR;g/d) & 16.69 & 1.48 & $12 \cdot 32$ & $2 \cdot 11$ \\
\hline Urinary excretion $(\mathrm{g} / \mathrm{d})$ & $10 \cdot 00$ & 1.10 & 10.79 & 0.63 \\
\hline Degradation $(\mathrm{g} / \mathrm{d})$ & 6.69 & $2 \cdot 58$ & $1 \cdot 53$ & 1.48 \\
\hline Pool size $(\mathrm{g})$ & 1.96 & $0 \cdot 18$ & 3.64 & $0 \cdot 71$ \\
\hline Space ( $1 / \mathrm{kg}$ live weight) & 0.52 & 0.01 & $0 \cdot 74$ & 0.03 \\
\hline \multicolumn{5}{|l|}{$\mathrm{N}$ metabolism } \\
\hline Intake $(\mathrm{g} / \mathrm{d})$ & 6.90 & 0.09 & 7.28 & $0 \cdot 29$ \\
\hline Urine $(\mathrm{g} / \mathrm{d})$ & $6 \cdot 76$ & 0.07 & $6 \cdot 34$ & 0.08 \\
\hline Faeces $(g / d)$ & $0 \cdot 14$ & 0.14 & $0 \cdot 00$ & 0.00 \\
\hline Retained (g/d) & 0.00 & 0.04 & $0 \cdot 94$ & 0.37 \\
\hline
\end{tabular}

* For details of procedures, see pp. 211-212.

$(P<0.05)$ in the rumen VFA mixture, but otherwise rumen conditions did not differ in any respect from those seen during the control periods when water alone was infused (Table 3 ). Although mean rumen $\mathrm{NH}_{3}$ concentration showed no significant change in response to PPDA infusion, considerable variability was evident between pairs of animals; sheep $C$ and $\mathrm{D}$, which had previously been subjected to intragastric infusion procedures, showed a decrease of $40 \%$ in rumen $\mathrm{NH}_{3}$ concentration, whereas sheep $\mathrm{A}$ and $\mathrm{B}$ showed an increase of $19 \%$ in $\mathrm{NH}_{3}$ concentration when PPDA was given into the rumen. In animals $\mathrm{C}$ and $\mathrm{D}$, sequential sampling of rumen contents in period 3 showed that the decrease in urease activity and in $\mathrm{NH}_{3}$ concentration, and the increase in urea concentration, occurred within $12 \mathrm{~h}$ of the start of PPDA infusion and remained unchanged thereafter.

The restoration of urease activity when PPDA infusion was terminated and the accompanying changes in rumen urea and $\mathrm{NH}_{3}$ concentrations are shown for the same two sheep in Fig. 1. No change in urease activity was seen over the first $24 \mathrm{~h}$ after withdrawal of PPDA from the rumen. A slow recovery of urease activity took place over the next $24 \mathrm{~h}$ and this was followed by a regular and more rapid recovery in activity levels over the period 48-100 h (Fig. 1(a)). These changes in urease were mirrored by changes in rumen urea concentrations, which decreased steadily from $24 \mathrm{~h}$ onwards and reached baseline values, comparable with untreated animals, at $54 \mathrm{~h}$ (Fig. 1(b)). Changes in rumen $\mathrm{NH}_{3}$ concentrations were less consistent, showing a general increase from $24 \mathrm{~h}$ onwards in one animal and little change in the other (Fig. 1(c)).

PPDA given into the abomasum caused a reduction in rumen urease activity to about $40 \%$ of that seen with water infusion $(P<0.01)$, but was without effect on rumen urea concentration or on any other index of rumen function (Table 3 ).

Examination of rumen contents from each animal on each treatment indicated that all bacterial populations consisted essentially of small Gram negative cocci and short rods with 


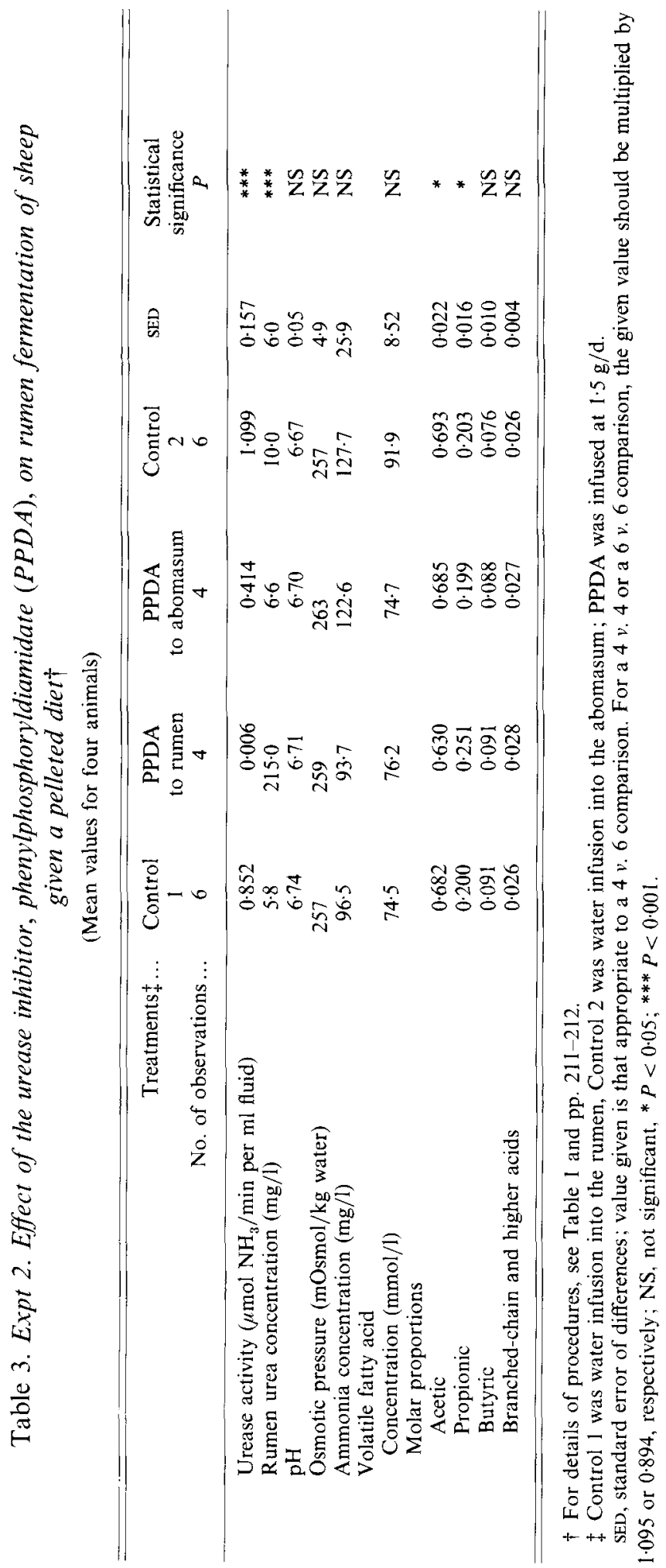



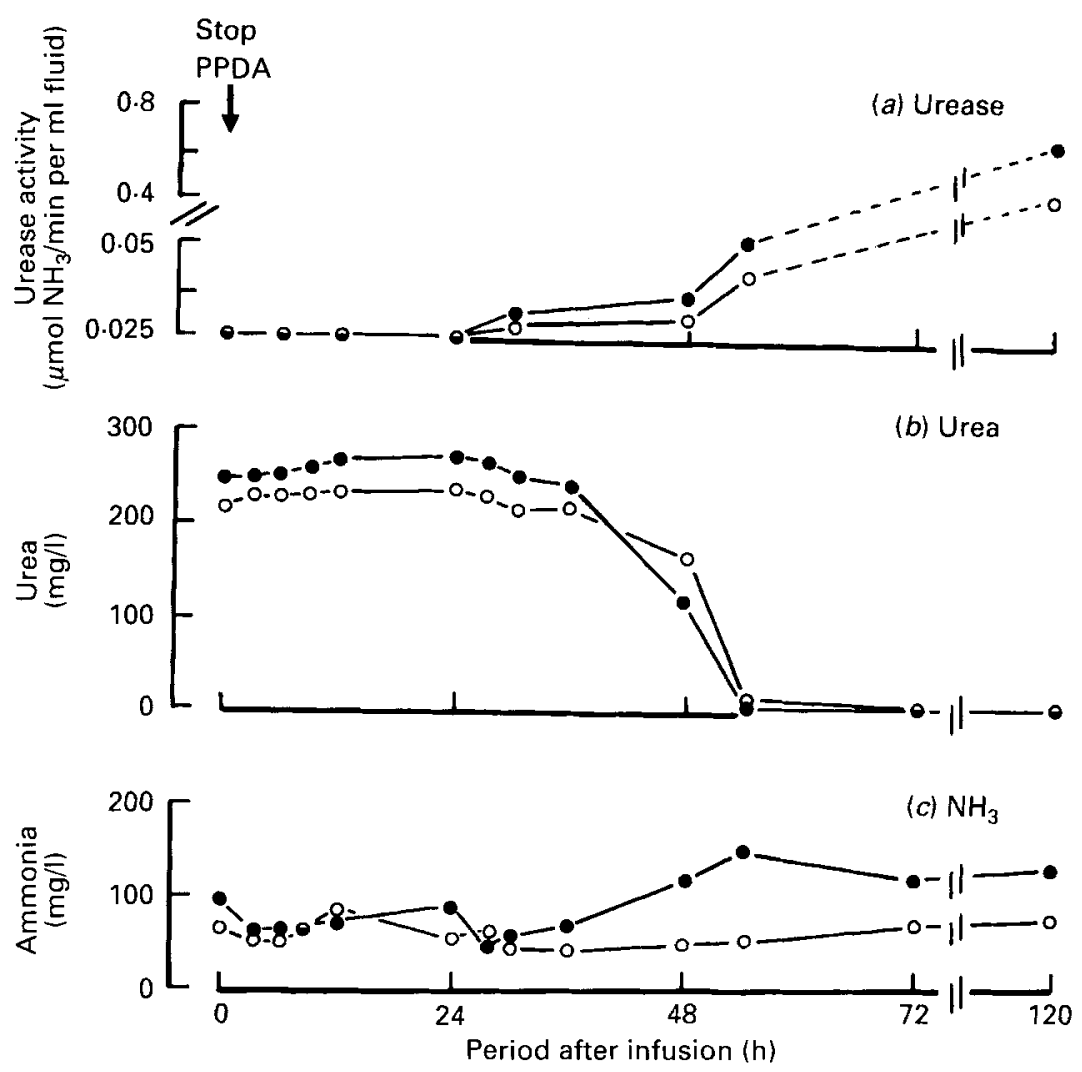

Fig. 1. Expt 2. Changes in urease $(E C 3.5 .1 .5)$ activity $(a)$ and in the concentrations of urea $(b)$ and ammonia (c) in rumen fluid of two sheep at intervals after stopping infusions of phenylphosphoryldiamidate (PPDA) to the rumen. For details of procedures, see pp. 211-212.

a small percentage (5-10) of Gram positive cocci. There were no obvious differences between sheep or between successive periods, other than the appearance of some larger rods (probably Oscillospira spp.) in sheep A and B during period 5. The examination of fixed samples of rumen contents for the presence of ciliate protozoa showed that all animals harboured large numbers of Entodinia spp. No other ciliates were seen and there were no obvious changes in population size in successive periods. A total count of organisms in period 3 indicated populations ranging from 4.4 to $12.4 \times 10^{5}$ organisms $/ \mathrm{ml}$ in different animals.

Urea and $N$ metabolism. The effects of PPDA administration on urea metabolism are summarized in Table 4. As noted for the sheep in Expt 1, plasma urea concentrations tended to be higher when PPDA was given. Urea ILR did not differ between the two control treatments or when PPDA was given into the abomasum, but showed a reduction of about $33 \%$ when PPDA was administered to the rumen $(P<0.001)$. There were no significant effects of treatment on urinary urea excretion and, in consequence, urea degradation was $58 \%$ lower when rumen urease was inhibited with PPDA $(P<0.001)$. Urea degradation as a proportion of ILR was also significantly lower $(P<0.001)$, and urea space significantly higher $(P<0.01)$ when PPDA was given into the rumen. Urea pool size tended to increase in response to both routes of PPDA administration but, this apart, infusions of PPDA at the abomasum had no significant effect on any of the indices of urea metabolism.

Findings relating to $\mathrm{N}$ metabolism and diet digestibility are given in Table 5. There was a small but significant increase $(P<0.05)$ in urinary $\mathrm{N}$ excretion in response to both routes 


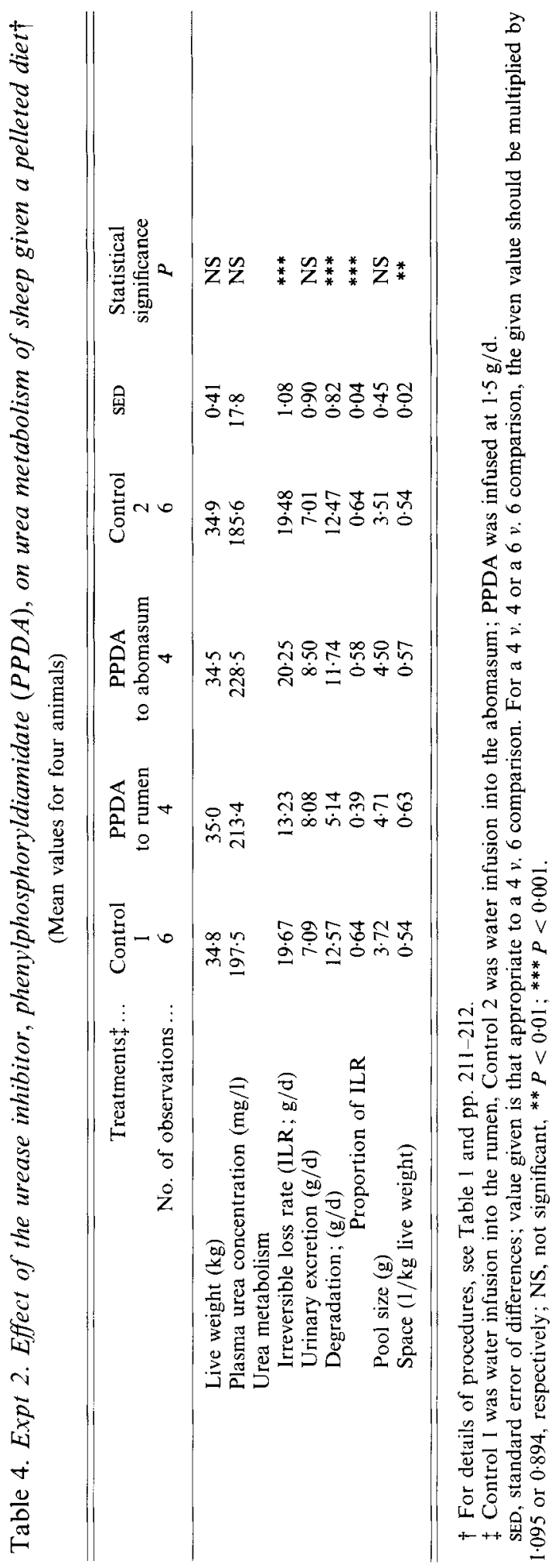




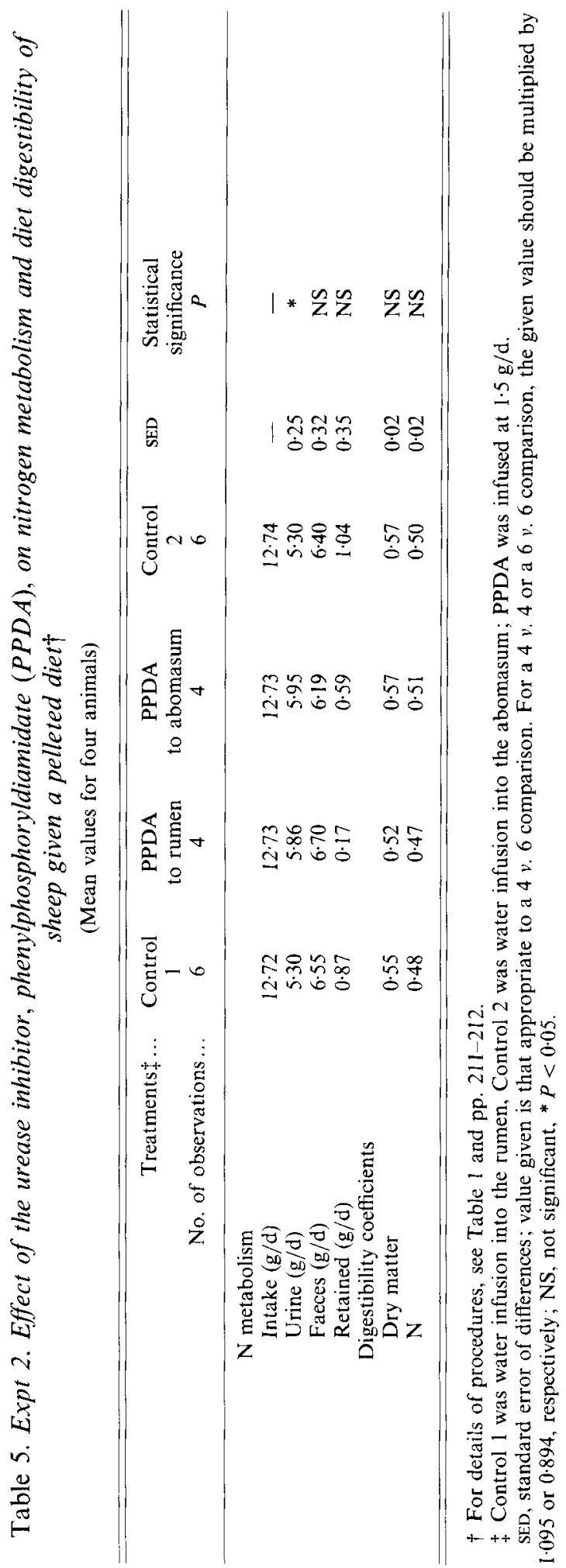



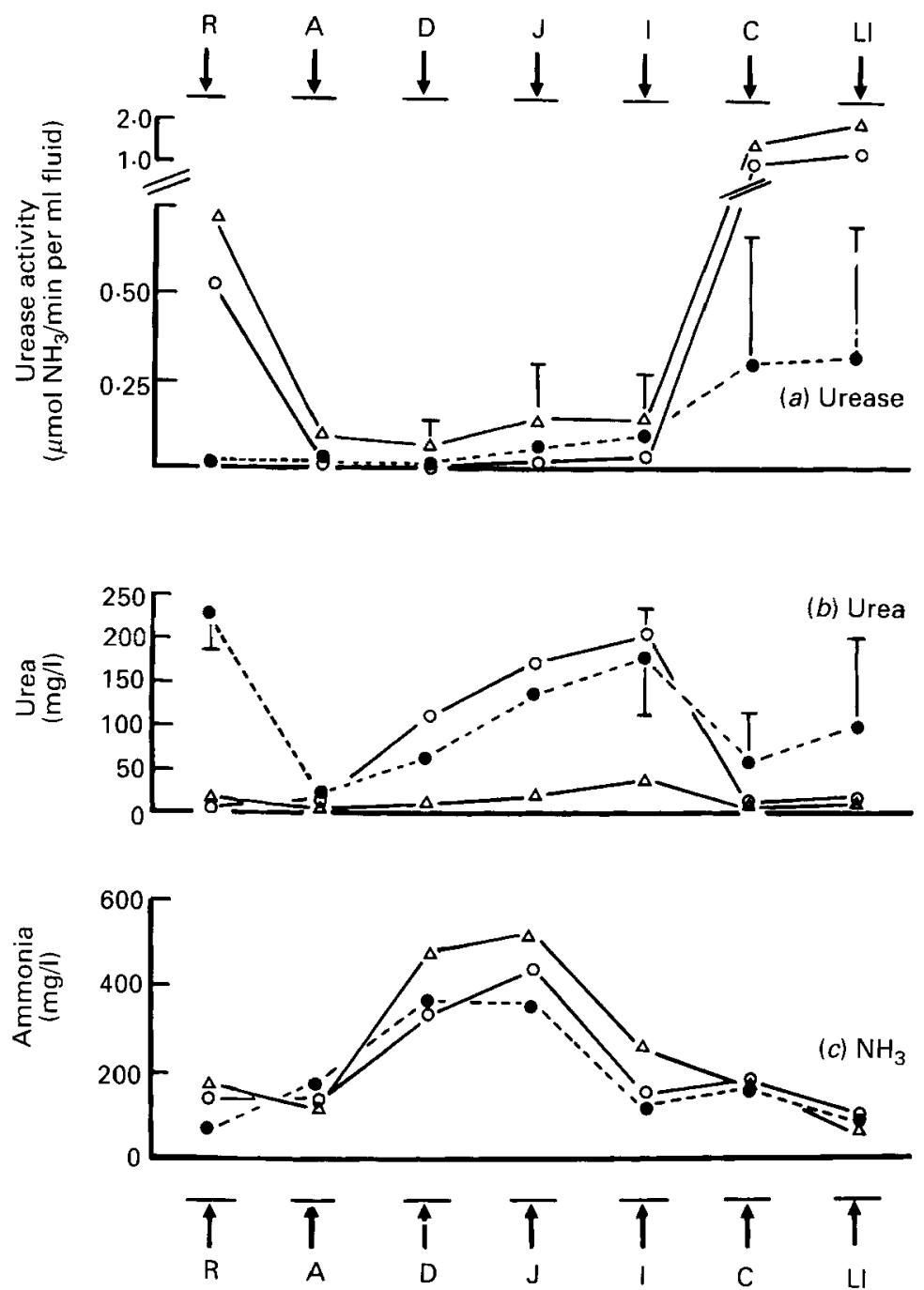

Fig. 2. Expt 3. Urease (EC 3.5.1.5) activity $(a)$ and concentrations of urea $(b)$ and ammonia $(c)$ in digesta of different segments of the gastrointestinal (GI) tract of animals receiving no phenylphosphoryldiamidate (PPDA) $(\triangle-\triangle)$ or given PPDA by infusion to the rumen $(-)$ ) or to the abomasum $(\mathrm{O}-\mathrm{O})$ for $5 \mathrm{~d}$ before slaughter. Points are mean values for two animals on each treatment and standard deviations are represented by vertical bars. Segments of the GI tract are: R, rumen-reticulum; A, abomasum; D, duodenum; J, jejunum; I, ileum; C, caecum; LI, large intestine. For details of procedures, see pp. 212-213.

of PPDA addition and this was reflected in rather lower values for $\mathrm{N}$ retention on these treatments; over all four treatments, however, differences in $\mathrm{N}$ retention were not significant. Additions of PPDA also had no significant effect on any measures of diet digestibility (Table 5).

\section{Expt 3}

Changes in urease activity and in urea and $\mathrm{NH}_{3}$ concentrations in different segments of the GI tract are illustrated in Fig. 2. These findings relate to only two animals per treatment, hence no statistical tests have been applied; where the variability encountered within a 
treatment group was considered sufficiently large to be of biological significance, this is indicated by error bars (SD) in Fig. 2. Urease activity throughout the small intestine was consistently lower in the presence than in the absence of PPDA, although the absolute differences in the measured urease activity levels were small. The effect of PPDA given into the rumen appeared to persist into the caecum and large intestine, but much of this effect could be attributed to one animal showing a very low urease activity in these segments (Fig. 2(a)).

A very marked decrease in urea concentration occurred between the reticulo-rumen and the abomasum in animals given PPDA into the rumen (Fig. 2(b)), suggesting the presence of a very effective mechanism for urea absorption in the region of the omasum. Despite the small differences in urease activity levels, urea concentrations increased throughout the length of the small intestine and were always considerably higher in animals given PPDA (Fig. 2(b)). Again, the effects apparent in the caecum and large intestine (Fig. 2(b)) were largely due to one particular animal. A retrospective examination of stored faeces samples for the presence of urea was carried out on samples selected at random (eight in all) from periods 2, 4 and 5. This showed that one animal given PPDA into the rumen had a urea concentration in faecal water of $258 \mathrm{mg} / \mathrm{l}$ while all other animals examined, irrespective of treatment, had concentrations of between 15 and $67 \mathrm{mg} / \mathrm{l}$. The animal concerned, however, was not the same as that showing high urea concentrations in caecum and large intestine in Fig. 2(b).

Concentrations of $\mathrm{NH}_{3}$ throughout the digestive tract did not differ according to the presence or absence of PPDA (Fig. 2(c)) and appeared to be independent of urease activity levels. This was true also of $\mathrm{pH}$ values throughout the GI tract which decreased from 6.6 (SD 0.1) in rumen contents to 2.5 (SD 0.3 ) in abomasum, and then increased gradually to values of about $7 \cdot 0-8 \cdot 0$ in caecum and large intestine in all animals examined.

\section{DISCUSSION \\ Inhibition of urease}

PPDA is clearly a very potent and reversible inhibitor of rumen bacterial urease. The dose rate used in this investigation was based on preliminary tests in vitro with rumen fluid from sheep nourished by infusion which indicated that PPDA concentrations of $100 \mathrm{mg} / 1$ were required for effective inhibition. Using an assumed rumen outflow rate of $101 / \mathrm{d}$, this value gives a daily dose of $1 \mathrm{~g} / \mathrm{d}$ for animals on infusion, and this was increased to $1.5 \mathrm{~g} / \mathrm{d}$ for animals given normal diets to compensate for possible effects of organic matter on PPDA activity (Martens \& Bremner, 1984). Over the time-scale examined in the present study, three successive challenges with PPDA (Expts 2 and 3) had no obvious adverse effects on the animals or on the gross morphological features of the rumen bacterial or protozoal populations. Apart from a possible interaction between previous nutrition (or, more likely, the nature of the bacterial populations subsequently established) and the process of $\mathrm{NH}_{3}$ formation in the rumen (p. 214), changes in microbial metabolism were confined to a modest shift in VFA proportions (Table 3). It seems safe to conclude therefore that the changes in urea metabolism noted were a direct consequence of the inhibition of urease by PPDA.

The most obvious change in urea metabolism in response to PPDA addition to the rumen was the accumulation of urea in rumen fluid and its rapid equilibration with plasma urea concentration. The relationship between mean plasma and rumen urea concentrations for the six animals examined is illustrated in Fig. 3, and is clearly rectilinear throughout the range of plasma urea concentrations encountered. This response to urease inhibition is fully consistent with the findings of Houpt \& Houpt (1968) in short-term rumen pouch studies 


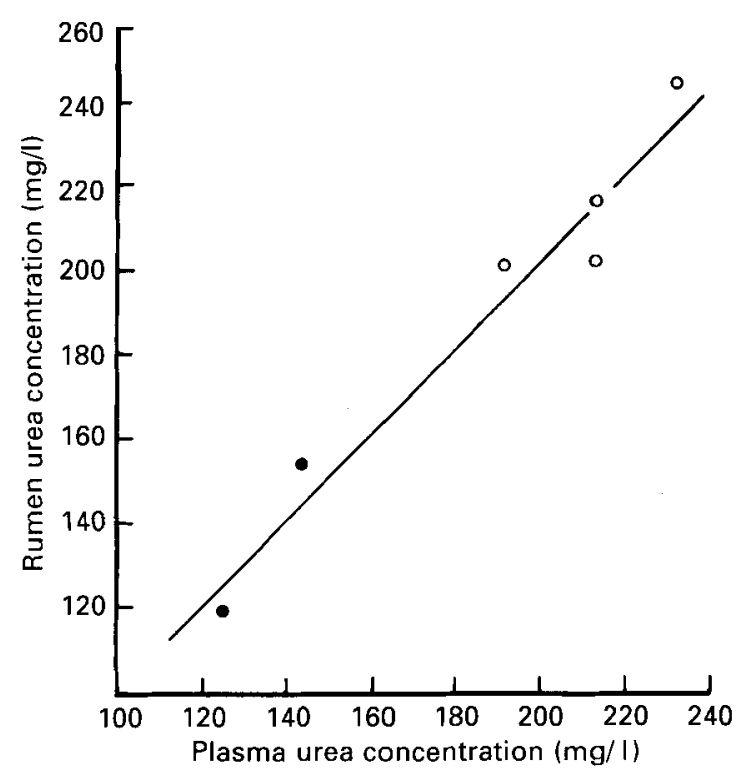

Fig. 3. Relationship between concentrations of urea in plasma and in rumen fluid of sheep nourished by intragastric infusion $(O)$ or given a pelleted diet $(O)$ and receiving infusions of phenylphosphoryldiamidate (PPDA) into the rumen. The equation of the regression line is $Y=1.02 X-0.23$.

which showed, first, that urea transfer from blood to rumen occurred rapidiy by simple diffusion and second, that once equilibrium was obtained no further net transport of urea would occur in either direction. Urea contained within the rumen at equilibrium thus simply enlarges the whole body urea pool and urea space (Table 4); in the present work, after allowing for the effect of differing plasma urea concentrations on urea pool size (Whitelaw et al. 1990), the changes in these measurements were consistent with mean rumen fluid volumes of 8.1 litres in Expt 1 and 3.1 litres in Expt 2. These values, in turn, are almost identical to the observed changes in urea space, 8.0 and 3.2 litres, which can be calculated from Tables 2 and 4 respectively.

We are aware of only one other report in which rumen urea concentrations have remained in equilibrium with urea in plasma over an extended period of time and this was in a study of gnotobiotic lambs lacking ureolytic bacteria and with no detectable urease activity in rumen fluid (Cheng \& Wallace, 1979). Ash \& Dobson (1963) and Thornton (1970) have reported the accumulation of both urea and $\mathrm{NH}_{3}$ in the washed and saline-filled rumen of sheep, but in neither case did urea concentration approach that in plasma.

The addition of PPDA to the abomasum in these experiments caused urease activity in rumen fluid to decrease by about $58 \%$ but had no significant effect on overall urea metabolism. Whether the effect in the rumen was due to absorption of PPDA into the bloodstream and its subsequent return to the rumen, or resulted simply from occasional reverse peristalsis of abomasal contents, is not known. Urease activity in the rumen clearly remained high enough to hydrolyse all urea presented. The absence of response to abomasal PPDA probably reflects the inactivation of the inhibitory effect at the $\mathrm{pH}$ encountered in abomasal digesta. Austin et al. (1984) have examined the hydrolysis of PPDA in the $\mathrm{pH}$ range 2-12 and reported a very rapid hydrolysis to $\mathrm{NH}_{3}$ and phenylphosphoramidate (PPA) at $\mathrm{pH}$ values of 2-3. PPA is also unstable in acid solution and PPDA was shown to be totally decomposed to phenyl phosphate and $\mathrm{NH}_{3}$ in about 
$20 \mathrm{~min}$ at pH 2 (Austin et al. 1984). The inhibition of urease activity and increasing concentrations of urea between abomasum and ileum for sheep given PPDA by the abomasal route (Fig. 2) presumably reflects only the action of any PPDA which has passed rapidly to the small intestine in a peristaltic rush and has, therefore, avoided prolonged exposure to low $\mathrm{pH}$. Despite the changes in metabolite concentration indicated in Fig. 2, the evidence suggests that this portion of the GI tract makes a minor contribution to urea degradation. Beyond the ileum a different situation prevails since hydrolysis of PPDA under basic conditions yields phenol and phosphorodiamidate (Austin et al. 1984), and this latter compound presumably retains some inhibitory action against urease (Dixon et al. 1975). However, five of the six animals examined showed urease activity in caecum and large intestine which was in excess of $0.5 \mu \mathrm{mol} \mathrm{NH} / 3 / \mathrm{min}$ per $\mathrm{ml}$ fluid, and this level appears to be adequate to hydrolyse all urea likely to be presented at these sites (Fig. 2).

\section{Urea and $N$ metabolism}

If urease inhibition is taken to be complete in the rumen as a result of PPDA addition, and to be confined to that organ, it can be calculated from Tables 2 and 4 that 23 and $41 \%$ of total urea degradation occurs in the post-rumen portion of the GI tract in animals nourished by infusion and those given normal feeds, respectively. The reduction in urea degradation resulting from inhibition of urease amounted to $516 \mathrm{~g} / \mathrm{d}$ in animals nourished by infusion and of this, $4.37 \mathrm{~g} / \mathrm{d}$ could be accounted for by a decrease in urea ILR and would represent that which was simply recycled through the $\mathrm{NH}_{3}$-urea regeneration loop and contributed anew to ILR (Table 2), as described by Whitelaw \& Milne (1991) and Whitelaw et al. (1991). In animals given normal feeds, the corresponding reduction in degradation relative to the mean of control groups 1 and 2 was $7.38 \mathrm{~g} / \mathrm{d}$, of which $6.34 \mathrm{~g} / \mathrm{d}$ contributed to ILR (Table 4$)$. The balance in each case $(0.80 \mathrm{~g}$ urea in infusion animals, $1.04 \mathrm{~g}$ in fed) presumably represents recycled urea which is incorporated into other compounds, or into microbial protein in the normally-fed animals, and is potentially available for productive purposes. Expressed as $\mathrm{N}$, these moieties account for only 5.4 and $3.8 \%$ respectively of daily $\mathrm{N}$ intake and further losses of $\mathrm{N}$ will occur in the subsequent metabolism of these fractions (Whitelaw et al. 1991). The potential contribution of recycled urea- $\mathrm{N}$ to whole body $\mathrm{N}$ retention is, thus, extremely low; in infusion animals, daily $\mathrm{N}$ retention was higher when PPDA was given (Table 2) and although slightly lower in normally-fed animals when urease was inhibited, differences between treatments in that experiment failed to reach statistical significance (Table 5). These findings accord with our previous observations on the effects of urea-recycling on whole-body $\mathrm{N}$ metabolism (Whitelaw \& Milne, 1991; Whitelaw et al. 1991) and suggest that the contribution of recycled urea- $\mathrm{N}$ can probably be ignored when calculating the protein requirements of ruminants consuming diets of moderate protein content.

\section{Control of urea transfer to the rumen}

The hypothesis proposed by Houpt (1970) regarding the role of urease in facilitating the transfer of urea-N from blood to rumen is no longer in dispute. Debate continues, however, about the mechanism whereby urea transfer to the rumen is abated by an increase in rumen $\mathrm{NH}_{3}$ concentration (Kennedy \& Milligan, 1980; Egan et al. 1986). In Houpt's (1970) scheme, $\mathrm{NH}_{3}$ transfer to the rumen is dependent on a favourable $\mathrm{NH}_{3}$ concentration gradient between epithelial tissue and rumen contents and implies an ongoing production of $\mathrm{NH}_{3}$ from urea, and the movement of $\mathrm{NH}_{3}$ into the portal blood stream, when rumen $\mathrm{NH}_{3}$ concentrations are high. An alternative scheme, proposed by Cheng \& Wallace (1979), invokes an inverse relationship between $\mathrm{NH}_{3}$ concentration and the expression of urease activity by the wall-adherent bacterial population and hence implies a reduction in urea 
hydrolysis through the partial or complete inhibition of urease when rumen $\mathrm{NH}_{3}$ concentration increases.

Some evidence pertinent to this debate can be adduced from the present findings. Adopting the assumption made above regarding the extent and site of urease inhibition, we can calculate from the observed changes in urea degradation that the rate of $\mathrm{NH}_{3}$ formation in the rumen epithelium was equivalent to $100 \mathrm{mg} \mathrm{N} / \mathrm{h}$ in Expt 1 and $144 \mathrm{mg} \mathrm{N} / \mathrm{h}$ in Expt 2. Thornton (1970) measured the rate of entry of $\mathrm{N}$ into the salinefilled rumen of conscious sheep given intravenous loads of urea and found the rate to be $90 \mathrm{mg} \mathrm{N} / \mathrm{h}$, irrespective of plasma urea concentration. Since the saline solutions were initially free of $\mathrm{NH}_{3}$ (Thornton, 1970), whereas the rumen $\mathrm{NH}_{3}$ concentrations in the present work were about $80-120 \mathrm{mg} / 1$ (Tables 2 and 3), it would appear that the rate of $\mathrm{NH}_{3}$ formation in the epithelium is not particularly responsive to changes in $\mathrm{NH}_{3}$ concentration gradient. This supports the concepts proposed by Houpt (1970) and suggests that backdiffusion of $\mathrm{NH}_{3}$ into portal blood must operate to limit transfer to the rumen when rumen $\mathrm{NH}_{3}$ concentration increases. Although we have no evidence in the present work of the relative proportions of hydrolysed urea- $\mathrm{N}$ which reached the rumen or diffused back to blood, neither route of $\mathrm{NH}_{3}$ removal would conflict with the observations on urea kinetics reported here. This explanation could also account for the finding in our previous work that urea degradation in the whole digestive tract remained remarkably constant when sheep were subjected to quite different physiological and dietary conditions (Whitelaw et al. 1990, 1991; Whitelaw \& Milne, 1991).

An inverse relationship between rumen $\mathrm{NH}_{3}$ concentration and urease activity was demonstrated by Cheng \& Wallace (1979) by infusion of ammonium carbonate solutions to the rumen of a sheep, but clear evidence that this mechanism controls urea transport to the rumen is lacking. Indeed, Norton et al. (1982) have calculated that the lowest urease level reported by Cheng \& Wallace (1979), $0.49 \mu \mathrm{mol} \mathrm{NH}_{3} / \mathrm{min}$ per ml fluid, would be sufficient to hydrolyse $49 \mathrm{~g}$ urea- $\mathrm{N}$ daily. This view is supported by the evidence in Fig. 1(b) which shows that all urea present in the rumen was fully hydrolysed at urease activity levels of only $0.05 \mu \mathrm{mol} \mathrm{NH} \mathrm{NH}_{3} / \mathrm{min}$ per ml fluid, a value about 10 times lower than that of Cheng $\&$ Wallace (1979). These urease values are also considerably lower than any reported for the rumen of the normally-fed animal and it is difficult to envisage, therefore, that urease inhibition by rumen $\mathrm{NH}_{3}$ concentration could be a regulator of urea transport across the rumen wall.

\section{Conclusions}

We conclude from these findings that PPDA is a potent inhibitor of rumen bacterial urease and its use in vivo allows the rumen and post-rumen components of urea recycling to be quantified. Urease inhibition in the rumen results in the rapid accumulation of urea in rumen contents and its equilibration with urea in plasma, indicating that urea transfer to the rumen occurs by simple diffusion. The contribution of degraded urea to whole-body $\mathrm{N}$ metabolism is small in the normal ruminant consuming a diet of moderate protein content and can probably be disregarded in estimating the dietary protein needs of such animals. Urease activity levels of only $0.05 \mu \mathrm{mol} \mathrm{NH}_{3} / \mathrm{min}$ per ml rumen fluid appear to be sufficient to hydrolyse all urea diffusing into the rumen epithelium.

The authors are grateful to Messrs VEB Kombinat Agrochemie Piesteritz, Cunnersdorf 7101, bei Leipzig, Germany, for the special synthesis and gift of PPDA. They acknowledge also the assistance of $\mathrm{Mr}$ G. Wenham and $\mathrm{Dr} \mathrm{D}$. A. H. Farningham in surgery, $\mathrm{Dr}$ M. F. Franklin in statistical analyses and Miss Maureen Annand and Mr R. I. Smart and their colleagues in chemical analyses. They are indebted also to Dr C. Stewart for 
microbiological examination of digesta samples and to $\mathrm{Mr}$ W. J. Shand for examination and counts of ciliate protozoa. They also wish to thank Dr E. R. Ørskov for his interest and encouragement and for providing financial assistance to S.A.W.

\section{REFERENCES}

Abdel Rahman, S. \& Decker, P. (1966). Comparative study of the urease in the rumen wall and rumen content. Nature 209, 618-619.

Agricultural Research Council (1984). The Nutrient Requirements of Ruminant Livestock, Suppl. No. 1. Farnham Royal, Slough: Commonwealth Agricultural Bureaux.

Ash, R. W. \& Dobson, A. (1963). The effect of absorption on the acidity of rumen contents. Journal of Physiology 169, 39-61.

Austin, E. R., Bradford, T. J. \& Lupin, M. S. (1984). High performance liquid chromatographic determination and hydrolysis studies of phenyl phosphorodiamidate, a urease inhibitor. Journal of Agricultural and Food Chemistry 32, 1090-1096.

Byrnes, B. H., Savant, N. K. \& Crasswell, E. T. (1983). Effect of a urease inhibitor phenyl phosphorodiamidate on the efficiency of urea applied to rice. Soil Science Society of America Journal 47, 270-274.

Cheng, K.-J., McCowan, R. P. \& Costerton, J. W. (1979). Adherent epithelial bacteria in ruminants and their roles in digestive tract function. American Journal of Clinical Nutrition 32, 139-148.

Cheng, K.-J. \& Wallace, R. J. (1979). The mechanism of passage of endogenous urea through the rumen wall and the role of ureolytic epithelial bacteria in the urea flux. British Journal of Nutrition 42, 553-557.

Dinsdale, D., Cheng, K.-J., Wallace, R. I. \& Goodlad, R. A. (1980). Digestion of epithelial tissue of the rumen wall by adherent bacteria in infused and conventionally fed sheep. Applied and Environmental Microbiology 39 , $1059-1066$.

Dixon, N. E., Gazzola, C., Watters, J. J., Blakely, R. L. \& Zerner, B. (1975). Inhibition of Jack Bean urease (EC 3.5.1.5) by acetohydroxamic acid and by phosphoramidate. An equivalent weight for urease. Journal of the American Chemical Society 97, 4130-4131.

Egan, A. R., Boda, K. \& Varady, J. (1986). Regulation of nitrogen metabolism and recycling. In Control of Digestion and Metabolism in Ruminants, pp. 386402 [L. P. Milligan, W. L. Grovum and A. Dobson, editors]. Englewood Cliffs, NJ: Prentice-Hall.

Genstat, (1987). Genstat 5 Reference Manual. Oxford: Clarendon Press.

Houpt, T. R. (1970). Transfer of urea and ammonia to the rumen. In, Physiology of Digestion and Metabolism in the Ruminant, pp. 119-131 [A. T. Phillipson, editor]. Newcastle-upon-Tyne: Oriel Press.

Houpt, T. R. \& Houpt, K. A. (1968). Transfer of urea nitrogen across the rumen wall. American Journal of Physiology 214, 1296-1303.

Jones, G. A. \& Milligan, J. D. (1975). Influence on some rumen and blood parameters of feeding acetohydroxamic acid in a urea-containing ration for lambs. Canadian Journal of Animal Science 55, 39-47.

Kennedy, P. M. \& Milligan, L. P. (1980). The degradation and utilization of endogenous urea in the gastrointestinal tract of ruminants : a review. Canadian Journal of Animal Science 60, 205-221.

Liao, C. F.-H. \& Raines, S. G. (1985). Inhibition of soil urease activity by amido derivatives of phosphoric and thiophosphoric acids. Plant and Soil 85, 149-152.

McCowan, R. P., Cheng, K. J., Bailey, C. B. M. \& Costerton, J. W. (1978). Adhesion of bacteria to epithelial cell surfaces within the reticulo-rumen of cattle. Applied and Environmental Microbiology 35, 149-155.

Marsh, W. H., Fingerhut, B. \& Miller, H. (1965). Automated and manual direct methods for the determination of blood urea. Clinical Chemistry 11, 624-627.

Martens, D. A. \& Bremner, J. M. (1984). Urea hydrolysis in soils: factors influencing the effectiveness of phenylphosphorodiamidate as retardent. Soil Biology and Biochemistry 16, 515-519.

Nolan, J. V. \& Leng, R. A. (1974). Isotope techniques for studying the dynamics of nitrogen metabolism in ruminants. Proceedings of the Nutrition Society 33, 1-8.

Norton, B. W., Janes, A. N. \& Armstrong, D. G. (1982). The effect of intraruminal infusions of sodium bicarbonate, ammonium chloride and sodium butyrate on urea metabolism in sheep. British Journal of Nutrition 48, $265-274$.

Oncuer, A., Milne, J. S. \& Whitelaw, F. G. (1990). The effect of a hind-gut fermentation on urea metabolism in sheep nourished by intragastric infusion. Experimental Physiology 75, 689-700.

Ørskov, E. R., Grubb, D. A., Wenham, G. \& Corrigall, W. (1979). The sustenance of growing and fattening ruminants by intragastric infusion of volatile fatty acids and protein. British Journal of Nutrition 41, 553-558.

Ørskov, E. R., Reid, G. W., Holland, S. M., Tait, C. A. G. \& Lee, N. H. (1983). The feeding value of ruminants of straw and whole crop barley and oats treated with anhydrous or aqueous ammonia or urea. Animal Feed Science and Technology 8, 247-257.

Piatkowski, B. \& Voigt, J. (1981). Investigations of the effect of phosphoric phenyl ester diamide as inhibitor of the rumen urease of dairy cows. 4. Feed intake and milk yield. Archives Tierernährung 31, 181-185.

Ross, G. J. S. (1980). Maximum Likelihood Programme, Version 3.07. Lawes Agricultural Trust, Rothamsted Experimental Station. 
Streeter, C. L., Oltjen, R. R., Slyter, L. L. \& Fishbein, W. N. (1969). Urea utilization in wethers receiving the urease inhibitor, acetohydroxamic acid. Journal of Animal Science 29, 88-93.

Thornton, R. F. (1970). Urea excretion in ruminants. II. Studies in sheep whose rumen contents were replaced with physiological saline. Australian Journal of Agricultural Research 21, 337-344.

Vlek, P. L. G., Stumpe, J. M. \& Byrnes, B. H. (1980). Urease activity and inhibition in flooded soil systems. Fertilizer Research 1, 19!-202.

Voigt, J., Piatkowski, B. \& Bock, J. (1980). Investigations of the effect of phosphoric phenyl ester diamide as inhibitor of the rumen urease of dairy cows. 1. Influence on urea hydrolysis, ammonia release and fermentation in the rumen. Archives Tierernährung 30, 811-823.

Whitelaw, F. G. \& Milne, J. S. (1991). Urea degradation in sheep nourished by intragastric infusion: effects of level and nature of energy inputs. Experimental Physiology. 76, 77-90.

Whitelaw, F. G., Milne, J. S. \& Chen, X. B. (1991). The effect of a rumen microbial fermentation on urea and nitrogen metabolism of sheep nourished by intragastric infusion. Experimental Physiology. 76, 9l-101.

Whitelaw, F. G., Milne, J. S., Ørskov, E. R., Stansfield, R. \& Franklin, M. (1990). Urea metabolism in sheep given conventional feeds or nourished by intragastric infusion. Experimental Physiology 75, 239-254. 